Kang, S., and Nicholls, S. (accepted 2020, due in press 2021). Determinants of Willingness to Pay for a Green Hotel Room: Evidence from Michigan, USA. International Journal of Hospitality

Management.

\title{
Determinants of Willingness to Pay to Stay at a Green Lodging Facility
}

\begin{abstract}
(150 words)
\end{abstract}
The adoption of green initiatives is attracting increasing attention among tourism providers and researchers. One important dimension of travellers' environmental concern is their willingness to pay higher rates for green travel products. This study determines the association between pro-environmental attitudes and beliefs, and willingness to pay a higher room rate at a green lodging facility. A survey of 388 travellers in Michigan, USA, revealed a positive relationship between environmental concern (measured using the New Environmental Paradigm scale) and willingness to pay for a green hotel room. Income was the only one of a series of socioeconomic, demographic and travel pattern variables to reach statistical significance. Additional evidence regarding consumer attitudes towards and concomitant behaviours with respect to travel and the environment is vital to the broader consideration of the sustainability of the tourism and hospitality sectors. Understanding of willingness to pay for green practices has important marketing and management implications.

Keywords: accommodations; attitudes; environment; New Environmental Paradigm; Michigan 


\section{Determinants of Willingness to Pay to Stay at a Green Lodging Facility}

Introduction

Market research continues to suggest increasing global concern with the sustainability practices of the companies from whom consumers purchase. Amongst US consumers, $87 \%$ would buy a product with an environmental or social benefit if given the opportunity (Cone Communications, 2017). According to Nielsen (2015), two-thirds of global consumers are willing to pay more for the products and services of companies committed to positive social and environmental impact, up from 50\% in 2013. Specific to the tourism sector, research by TripAdvisor (2015) suggests that $71 \%$ of global travellers place importance on properties implementing eco-friendly practices.

The potential for adoption of green initiatives within the tourism sector therefore continues to attract the attention of both academic researchers and travel providers (see, e.g., Manganari, Dimara \& Theotokis (2016) for a recent review). This study investigates the relationship between travellers' concern for the environment and their inclination to spend more to minimise the negative impacts of their hotel stays. Specifically, it determines the association between pro-environmental attitudes and beliefs, and willingness to pay a higher rate for a room at a green lodging facility.

Review of Literature

Willingness to pay (WTP) for green initiatives has been investigated in a variety of contexts, including the protection of threatened and endangered species (as reviewed by Lew (2015)), product packaging (e.g., Singh \& Pandey, 2018), and green products in air travel (e.g., Hinnen, Hille \& Wittmer, 2017). Though numerous studies have considered WTP for green hotel rooms, and some have also collected data concerning environmental attitudes and 
beliefs (e.g., Millar \& Mayer, 2013), few have explicitly associated these two foci in their analyses.

The willingness to pay literature has often been founded on Azjen's (1991) theory of planned behaviour (TPB), which suggests that an individual's behavioural intentions, and his or her eventual behaviours, are determined by one's attitude towards the behavior, subjective norms, and perceived behavioural control. Stated willingness to pay more for a green product or service (a behavioural intention), for example, might therefore be positively influenced by one's personal sense of what is 'the right thing to do' and one's perception of social normative pressures, but limited by the belief that any one person's behaviour is unlikely to make any tangible change, or by an actual or perceived lack of availability or access.

Social identity theory (Tajfel \& Turner, 1986) can also be used to support the expectation of a positive association between level of environmental concern and WTP to support green practices, based on the tendency for consumers to be attracted to entities with enduring and distinctive identities that can elevate the individual's sense of self-esteem. As such, a traveller with a high level of concern for the environment can be expected to identify more closely with travel providers that demonstrate a commitment to the reduction of their environmental footprint (as proposed by Kang, Stein, Heo \& Lee, 2012). Means-end theory (Gutman, 1982) provides an additional basis for this expected relationship, since it suggests that consumers view the purchase of certain products and services as a means to achieving their desired personal values including a sense of self-esteem around one's purchasing habits and the impacts thereof.

Alternatively, some research has suggested that people's behaviours whilst travelling do not always match those they exhibit when they are at home, i.e., that tendencies towards green behaviours in a household setting are not always replicated on vacation (Baker, Davis, and Weaver, 2014; Dolnicar \& Leisch, 2008a; Miao \& Wei, 2013). These findings might 
suggest a lack of willingness to pay any premium for green initiatives when travelling for leisure purposes.

WTP to stay at a green lodging facility

A comprehensive search of the literature revealed 20 studies that have assessed respondents' WTP more to stay in a green hotel in concept; 12 of those studies included one or more additional questions regarding the absolute or percentage premium that respondents would be willing to pay. The contexts and findings of these studies are highlighted in Table 1.

Evidence with regards to WTP remains mixed. From the earliest analyses in the mid1990s through the mid-2000s, the proportion of those willing to pay a hypothetical, unspecified premium varied for the most part within the $15-25 \%$ range across US, Malaysian and Indian contexts (Gustin \& Weaver, 1994; Kasim, 2004; Manaktola \& Jauhari, 2007; Watkins, 1994), with the exception of a Kenyan-based analysis which indicated WTP a premium amongst $67 \%$ of respondents (Masau \& Prideaux, 2003). More recent studies have indicated WTP proportions ranging from $10 \%$ of respondents (among leisure travellers in the US, according to Millar and Baloglu [2011]) to 94\% (hotel guests in Peniche, Portugal, per Borisenko [2018]), with most analyses indicating WTP a premium among between $40 \%$ and $80 \%$ of study participants. Direct comparison is, however, prohibited by variations in response options recorded, e.g., some studies have allowed only two options (willing to pay more, not willing to pay more) or three options (willing to pay more, unsure/neutral, not willing to pay more), whilst others have used 5-point Likert-type scales to assess (dis)agreement. 


\begin{tabular}{|c|c|c|c|c|c|}
\hline \multirow{2}{*}{$\begin{array}{l}\text { Author (Year) } \\
* \text { indicates } \\
\text { refereed }\end{array}$} & \multirow{2}{*}{$\begin{array}{l}\text { Study Summary: Location, } \\
\text { Sample Type and Size(s) }\end{array}$} & \multicolumn{3}{|c|}{ Willingness to Pay Less/More (in concept) } & \multirow[t]{2}{*}{ Willingness to Pay (by amount) } \\
\hline & & Less/No & $\begin{array}{c}\text { Same/Neutral/ } \\
\text { Unsure }\end{array}$ & More/Yes & \\
\hline $\begin{array}{l}\text { Gustin \& } \\
\text { Weaver (1994) }\end{array}$ & Washington, USA; & $24 \%$ & $49 \%$ & $27 \%$ & N/A \\
\hline $\begin{array}{l}\text { Watkins } \\
(1994)^{*}\end{array}$ & $\begin{array}{c}\text { Atlanta. Georgia and } \\
\text { Washington, DC, USA; survey } \\
\text { distributed to travellers passing } \\
\text { through airports; } \mathrm{n}=397 \\
\end{array}$ & \$5-10 less: $23 \%$ & Same: $49 \%$ & $\begin{array}{l}\text { \$5-10 more: } \\
27 \%\end{array}$ & N/A \\
\hline $\begin{array}{l}\text { Masau \& } \\
\text { Prideaux (2003) }\end{array}$ & $\begin{array}{c}\text { Kenya; random survey of hotel } \\
\text { guests; } n=237\end{array}$ & Not stated & Not stated & More: $66.5 \%$ & N/A \\
\hline $\operatorname{Kasim}(2004)^{*}$ & $\begin{array}{c}\text { Pulau Pinang, Malaysia; } \\
\text { survey distributed to random } \\
\text { stratified sample of airport } \\
\text { travellers; } \mathrm{n}=225\end{array}$ & $\begin{array}{l}\text { Would never pay } \\
\text { more: } 37 \%\end{array}$ & Undecided: $38 \%$ & $\begin{array}{l}\text { Would pay more } \\
\text { without } \\
\text { hesitation: } 25 \%\end{array}$ & N/A \\
\hline $\begin{array}{l}\text { Fairweather, } \\
\text { Maslin \& } \\
\text { Simmons } \\
(2005)^{*}\end{array}$ & $\begin{array}{l}\text { Christchurch, New Zealand; } \\
\text { interviews based on quota } \\
\text { sample of visitors; } n=295\end{array}$ & \multicolumn{3}{|c|}{$\begin{array}{l}\text { Mean score in response to item regarding willingness to } \\
\text { pay more for green travel products/services } 3.53 \text { on a } 5 \\
\text { point scale ( } 3.94 \text { for biocentric respondents, } 2.91 \text { for } \\
\text { ambivalents, difference significant) }\end{array}$} & $\begin{array}{l}\text { Biocentric respondents willing TP } 7.2 \% \\
\text { more for accommodation with an } \\
\text { ecolabel, ambivalents } 3.4 \% \text { more } \\
\text { (difference significant) }\end{array}$ \\
\hline $\begin{array}{l}\text { Kelly et al. } \\
(2007)\end{array}$ & $\begin{array}{l}\text { Whistler, British Columbia, } \\
\text { Canada; online survey of } \\
\text { randomly intercepted summer } \\
\text { visitors; } \mathrm{n}=876 \\
\end{array}$ & N/A & N/A & $\mathrm{N} / \mathrm{A}$ & $\begin{array}{l}\text { Both overnight and day visitors willing } \\
\text { to accept environmental tax of } 2 \% \text { or } 4 \% \\
\text { charged to their accommodation, } \\
\text { restaurant and activity bills } \\
\end{array}$ \\
\hline $\begin{array}{l}\text { Manaktola \& } \\
\text { Jauhari (2007) }\end{array}$ & $\begin{array}{c}\text { National Capital Region, } \\
\text { India; convenience sample of } \\
\text { consumers; } n=66\end{array}$ & N/A & N/A & More: $15 \%$ & $\begin{array}{c}\text { Of the } 15 \%, 11 \% \text { WTP } 25 \% \text { of hotel's } \\
\text { cost, } 40 \% \text { feel hotel should pay } 50-100 \% \\
\text { of costs, } 40 \% \text { would pay } 4-6 \% \text { more }\end{array}$ \\
\hline $\begin{array}{l}\text { Dalton et al. } \\
(2008)\end{array}$ & $\begin{array}{c}\text { Australia; surveys and } \\
\text { interviews of hotel guests; } n= \\
280\end{array}$ & \multicolumn{2}{|c|}{ Less or same: $52 \%$} & More: $48 \%$ & Of the $48 \%, 92 \%$ WTP $1-5 \%$ more \\
\hline $\begin{array}{l}\text { Yesawich } \\
(2008)\end{array}$ & $\begin{array}{c}\text { Ypartnership/Yankelovich US } \\
\text { National Travel Monitor }\end{array}$ & $53 \%$ & N/A & $47 \%$ & $\begin{array}{c}\text { Of the } 47 \%, 60 \% \text { would pay up to } 9 \% \\
\text { more }\end{array}$ \\
\hline $\begin{array}{l}\text { Choi et al. } \\
(2009)^{*}\end{array}$ & $\begin{array}{l}\text { Greece and USA; convenience } \\
\text { sample of students; } n=200\end{array}$ & \multicolumn{2}{|c|}{$\begin{array}{l}\text { Will not pay more: Greek } \\
\text { respondents } 35.6 \% \text {, US } 33.8 \%\end{array}$} & $\begin{array}{l}\text { Will pay more: } \\
\text { Greek } 64.4 \% \text {, } \\
\text { US } 66.2 \%\end{array}$ & $\begin{array}{c}\text { Of those WTP more ... } \\
\text { Greek: } 2-6 \% \text { more } 35.6 \%,>6 \% 28.8 \% \\
\text { US: } 2-6 \% 32.4 \%,>6 \% 33.8 \% \\
\end{array}$ \\
\hline
\end{tabular}




\begin{tabular}{|c|c|c|c|c|c|}
\hline $\begin{array}{l}\text { Tartaglia \& de } \\
\text { Grosbois (2009) }\end{array}$ & $\begin{array}{l}\text { Niagara Falls; survey of } \\
\text { visitors; } n=52\end{array}$ & $\begin{array}{l}\text { Not willing to } \\
\text { pay extra: } 15 \%\end{array}$ & Neutral: $27 \%$ & $\begin{array}{l}\text { Willing to pay } \\
\text { extra: } 58 \%\end{array}$ & N/A \\
\hline $\begin{array}{l}\text { Kuminoff et al. } \\
(2010)^{*}\end{array}$ & $\begin{array}{l}\text { Virginia, USA; online search } \\
\text { for green and brown hotels; } n \\
\qquad=223\end{array}$ & N/A & N/A & N/A & $\begin{array}{c}\text { Premium on room rate at a green hotel of } \\
\text { between } \$ 8.97 \text { and } \$ 25.43 \text { (relative to } \\
\text { average rate of } \$ 99.12 \text { ) }\end{array}$ \\
\hline $\begin{array}{l}\text { Millar \& } \\
\text { Baloglu }(2011)^{*}\end{array}$ & $\begin{array}{l}\text { USA; online survey of } \\
\text { travellers; } n=284 \text { (business, } \\
\text { B) and } 287 \text { (leisure, } L \text { ) }\end{array}$ & $\begin{array}{l}\text { Less: } \\
\text { B } 4.6 \% \\
\text { L } 6.3 \%\end{array}$ & $\begin{array}{l}\text { Same: } \\
\text { B } 77.5 \% \\
\text { L } 84.0 \% \\
\end{array}$ & $\begin{array}{l}\text { More: } \\
\text { B } 18.0 \% \\
\text { L } 9.8 \%\end{array}$ & $\begin{array}{c}\mathrm{B}: 5 \%=33.3 \%, 10 \%=51.0 \%, 15 \%= \\
15.7 \% ; \mathrm{L}: 5 \%=35.7 \%, 10 \%=50.0 \% \\
15 \%=14.3 \%\end{array}$ \\
\hline $\begin{array}{l}\text { Susskind \& } \\
\text { Verma }(2011)\end{array}$ & & Not stated & Not stated & More: $45 \%$ & N/A \\
\hline $\begin{array}{l}\text { Tsagarakis et al. } \\
(2011)^{*}\end{array}$ & $\begin{array}{l}\text { Crete, Greece; interviews of } \\
\text { travellers passing through } \\
\text { airports; } n=2,308\end{array}$ & N/A & N/A & $\begin{array}{c}\text { Energy saving } \\
\text { installations } \\
75 \%, \text { renewable } \\
\text { energy sources } \\
77 \%\end{array}$ & N/A \\
\hline $\begin{array}{l}\text { Kang et al. } \\
(2012)^{*}\end{array}$ & $\begin{array}{l}\text { Arizona, Florida, Texas, USA; } \\
\text { online survey of requestors of } \\
\text { tourism information from } \\
\text { destination marketing } \\
\text { organizations; } \mathrm{n}=455\end{array}$ & $\begin{array}{c}\text { Totally disagree: } \\
20.6 \% \\
\text { Partially } \\
\text { disagree: } 16.8 \%\end{array}$ & Neutral: $33.0 \%$ & $\begin{array}{l}\text { Totally agree: } \\
5.5 \% \\
\text { Partially agree: } \\
24.1 \%\end{array}$ & $\begin{array}{c}0 \%=33.6 \%, 1-5 \%=37.4 \%, 6-10 \%= \\
23.5 \%, 11-15 \%=3.7 \%, 16-20 \%=0.9 \% \\
>20 \%=0.9 \%\end{array}$ \\
\hline Ogbeide (2012) & $\begin{array}{l}\text { Texas and Arkansas, USA; } \\
\text { convenience sample; } \mathrm{n}=241\end{array}$ & \multicolumn{2}{|c|}{ Willing to pay less or the same: $75 \%$} & $\begin{array}{l}\text { Willing to pay } \\
\text { more: } 25 \%\end{array}$ & N/A \\
\hline $\begin{array}{l}\text { Han \& Chan } \\
(2013)^{*}\end{array}$ & $\begin{array}{l}\text { Hong Kong; interviews with } \\
\text { inbound visitors; } n=30\end{array}$ & \multicolumn{2}{|c|}{ Not willing to pay more: $23 \%$} & $\begin{array}{l}\text { Would pay } \\
\text { more: } 77 \%\end{array}$ & $\begin{array}{c}1-5 \%=13 \%, 6-10 \%=43 \%, 11-15 \%= \\
17 \%\end{array}$ \\
\hline $\begin{array}{l}\text { Chia-Jung \& } \\
\text { Pei-Chun } \\
(2014)^{*}\end{array}$ & $\begin{array}{c}\text { Taiwan; face-to-face } \\
\text { convenience interview/survey; } \\
\mathrm{n}=390\end{array}$ & N/A & N/A & N/A & $\begin{array}{l}\text { Cooperation with environmentally } \\
\text { friendly behaviours associated with room } \\
\text { price reduction of }-\mathrm{NT} \$ 337 \text { (US\$11.20) }\end{array}$ \\
\hline $\begin{array}{l}\text { Sánchez-Ollero } \\
\text { et al. }(2014)^{*}\end{array}$ & $\begin{array}{l}\text { Andalusia, Spain; survey of } \\
\text { hotel managers; } n=232\end{array}$ & N/A & N/A & N/A & $\begin{array}{c}\text { Premium on room rate of } € 5.00(5.15 \%) \\
\text { per green measure implemented (relative } \\
\text { to average rate of } € 99.12)\end{array}$ \\
\hline $\begin{array}{l}\text { Susskind } \\
(2014)^{*}\end{array}$ & $\begin{array}{c}\text { Ithaca, New York, USA; } \\
\text { survey of randomly selected } \\
\text { hotel guests; } n=192\end{array}$ & No: $55 \%$ & N/A & Yes: $45 \%$ & N/A \\
\hline
\end{tabular}




\begin{tabular}{|c|c|c|c|c|c|}
\hline $\begin{array}{l}\text { Dimara et al. } \\
\text { (2015) }\end{array}$ & $\begin{array}{c}\text { Greece; face-to-face } \\
\text { interviews/surveys with } \\
\text { domestic visitors; } n=678\end{array}$ & No: $56.3 \%$ & N/A & Yes: $43.7 \%$ & $€ 2.4$ \\
\hline Nyström (2017) & $\begin{array}{c}\text { Stockholm, Sweden; survey of } \\
\text { hotel guests; } n=481\end{array}$ & No: $58 \%$ & N/A & Yes: $42 \%$ & $\begin{array}{c}\text { Average SEK148.82, range SEK0- } \\
1437.63\end{array}$ \\
\hline $\begin{array}{l}\text { Borisenko } \\
\text { (2018) }\end{array}$ & $\begin{array}{c}\text { Peniche, Portugal; two } \\
\text { convenience samples of hotel } \\
\text { guests; } \mathrm{n}=105 \text { (in-person, I) } \\
\text { and } 128(\text { online }, \mathrm{O})\end{array}$ & $\begin{array}{l}\text { (Strongly) } \\
\text { Disagree: } \\
\text { I } 1.0 \% \\
\text { O } 25.8 \%\end{array}$ & $\begin{array}{l}\text { Neutral: } \\
\text { I } 4.8 \% \\
\text { O } 28.1 \%\end{array}$ & $\begin{array}{l}\text { (Strongly) } \\
\text { Agree: } \\
\text { I } 94.3 \% \\
\text { O } 46.1 \%\end{array}$ & $\begin{array}{c}\text { I: } 0 \%=3.4 \%, 1-5 \%=36.2 \%, 6-10 \%= \\
51.4 \%, 11-15 \%=8.6 \%, 16-20 \%=0.0 \% \\
>20 \%=0.0 \% \\
\text { O: } 0 \%=7.0 \%, 1-5 \%=40.6 \%, 6-10 \%= \\
39.8 \%, 11-15 \%=10.9 \%, 16-20 \%= \\
0.8 \%,>20 \%=0.8 \%\end{array}$ \\
\hline $\begin{array}{l}\text { Rahman } \\
(2018)^{*}\end{array}$ & $\begin{array}{l}\text { USA; online sample of over } \\
\text { 21s using Amazon's } \\
\text { Mechanical Turk; } n=375\end{array}$ & \multicolumn{3}{|c|}{$\begin{array}{l}\text { Mean score in response to item regarding willingness to } \\
\text { pay more to stay at a green hotel } 4.07 \text { on a } 7 \text { point scale } \\
\text { (no significant difference with level of involvement) }\end{array}$} & N/A \\
\hline
\end{tabular}


Table 1. Summary of Prior Green Lodging WTP Studies

Of the studies that included additional questioning regarding the amount respondents would be willing to pay, the majority suggest a premium of up to $10 \%$ of the price of a regular room. Again, however, comparison is hampered by the variety of different approaches to the asking of, and answer options associated with, this item.

Also included in Table 1 are a pair of studies that assessed green hotel premiums using a revealed preference rather than hypothetical approach. Hedonic models of actual room rates demonstrated premiums of 9-25\% in Virginia, USA (Kuminoff, Zhang \& Rudi, 2010) and 5\% per green measure implemented in Andalusia, Spain (Sánchez-Ollero, GarcíaPozo \& Marchante-Mera, 2014). A final study considered the addition of an environmental tax to accommodation, restaurant and activity charges; both overnight and day visitors to Whistler, British Columbia, were willing to accept such a tax in an amount up to $2-4 \%$.

Determinants of WTP more to stay at a green lodging facility

Studies that have attempted to determine explanators of WTP more to stay at a green lodging facility are summarised in Table 2. A range of potential independent variables have been assessed, somewhat reducing the comparability of findings.

Of the seven studies that have considered the impact of gender on WTP, representing ten sets of analysis, females exhibited a significantly greater WTP in four cases and males the greater WTP in two. In the remaining four cases, no significant differences were found. In one other study, the effect of hotel image on WTP was greater among females. For age, across ten sets of analysis, older respondents appeared more prone to pay more in one instance and younger respondents in three instances, with five findings of insignificance and a final set of mixed results. In one other study, the effect of hotel image on WTP was greater among older respondents. The most common finding with respect to the influence of 
education on WTP has been one of insignificance (in six of nine cases), an observation that is also true for work status (insignificant in three of five analyses) and income (insignificant in four of six analyses).

Nine prior studies have included one or more explanatory variables representing ecoawareness, beliefs, attitudes and/or actions. In most cases, respondents exhibiting higher levels on these dimensions have indicated a higher WTP for green lodging. Kang et al. (2012), for example, found that those US hotel guests with higher levels of environmental concern were indeed willing to pay a premium for hotels' green initiatives; similarly, Rahman and Reynolds (2016) found a positive relationship between willingness to sacrifice for the environment and WTP.

The current analysis builds on this set of previous studies in an effort to further investigate the relationship between travellers' concern for the environment - as measured by pro-environmental attitudes and beliefs - and their WTP more for a green hotel room. More specifically, it attempts to disentangle the influence of those attitudes and beliefs based on their measurement, considering them first in aggregate, as an average, and second across individual sub-scales. 


\begin{tabular}{|c|c|c|c|c|c|c|c|c|c|c|}
\hline & $\begin{array}{c}\text { Study Summary: Location, } \\
\text { Sample Type and Size(s), } \\
\text { Analysis Technique }\end{array}$ & Gender & Age & Education & $\begin{array}{l}\text { Work } \\
\text { Status }\end{array}$ & $\begin{array}{c}\text { Marital } \\
\text { Status }\end{array}$ & Income & $\begin{array}{l}\text { Having/N } \\
\text { umber of } \\
\text { Children }\end{array}$ & Origin & $\begin{array}{c}\text { Trip } \\
\text { Purpose }\end{array}$ \\
\hline $\begin{array}{l}\text { Han et al. } \\
(2009)^{*}\end{array}$ & $\begin{array}{c}\text { USA; online survey of } \\
\text { general hotel customers; } \mathrm{n}= \\
371 ; \text { SEM }\end{array}$ & $\begin{array}{l}\text { Effect of } \\
\text { image on } \\
\text { WTP } \\
\text { greater for } \\
\text { females }\end{array}$ & $\begin{array}{l}\text { Effect of } \\
\text { image on } \\
\text { WTP } \\
\text { greater for } \\
\text { older } \\
\text { group } \\
\end{array}$ & - & - & - & - & - & - & - \\
\hline $\begin{array}{l}\text { Han et al. } \\
(2011)^{*}\end{array}$ & $\begin{array}{c}\text { USA; online survey of } \\
\text { general hotel customers; } n= \\
\text { 422; analysis of variance, } \\
\text { multiple regression analysis }\end{array}$ & Females & Insig. & Insig. & - & - & Insig. & - & - & - \\
\hline $\begin{array}{l}\text { Tsagarakis } \\
\text { et al. } \\
(2011)^{*}\end{array}$ & $\begin{array}{l}\text { See Table x for sample } \\
\text { summary; binary logistic } \\
\text { regression; ESI indicates } \\
\text { hotels with energy saving } \\
\text { installations, RES hotels with } \\
\text { renewable energy sources }\end{array}$ & $\begin{array}{l}\text { ESI: } \\
\text { females } \\
\text { RES: } \\
\text { insig. }\end{array}$ & $\begin{array}{l}\text { ESI: insig. } \\
\text { RES: } \\
\text { younger }\end{array}$ & $\begin{array}{c}\text { ESI: } \\
\text { university } \\
\text { graduates } \\
\text { RES: } \\
\text { insig. }\end{array}$ & - & - & $\begin{array}{l}\text { ESI: insig. } \\
\text { RES: } \\
\text { middle } \\
\text { income }\end{array}$ & $\begin{array}{l}\text { ESI: those } \\
\text { with } \\
\text { children } \\
\text { RES: } \\
\text { insig. }\end{array}$ & - & - \\
\hline $\begin{array}{l}\text { Kang et al. } \\
(2012)^{*}\end{array}$ & $\begin{array}{c}\text { See Table } 1 \text { for sample } \\
\text { summary; } \mathrm{U} \text { indicates } \\
\text { univariate analysis, } \mathrm{M} \\
\text { multiple regression analysis }\end{array}$ & $\begin{array}{l}\text { U: males } \\
\text { M: males }\end{array}$ & $\begin{array}{c}\text { Insig. in } \\
\text { both cases }\end{array}$ & $\begin{array}{l}\text { Insig. in } \\
\text { both cases }\end{array}$ & $\begin{array}{l}\text { Insig. in } \\
\text { both cases }\end{array}$ & $\begin{array}{c}\text { Insig. in } \\
\text { both cases }\end{array}$ & $\begin{array}{l}\text { U: insig. } \\
\text { U: lower } \\
\text { income }\end{array}$ & $\begin{array}{l}\text { Insig. in } \\
\text { both cases }\end{array}$ & - & - \\
\hline $\begin{array}{l}\text { Susskind } \\
(2014)^{*}\end{array}$ & $\begin{array}{c}\text { See Table } 1 \text { for sample } \\
\text { summary; multiple regression }\end{array}$ & Females & Older & - & - & - & Insig. & - & - & - \\
\hline $\begin{array}{l}\text { Dimara et } \\
\text { al. }(2015)\end{array}$ & $\begin{array}{c}\text { See Table } \mathrm{x} \text { for sample } \\
\text { summary; univariate analysis }\end{array}$ & Insig. & Younger & Insig. & - & - & - & - & - & - \\
\hline $\begin{array}{l}\text { Nyström } \\
\text { (2017) }\end{array}$ & $\begin{array}{l}\text { See Table } x \text { for sample } \\
\text { summary; regression } \\
\text { (Cragg's Tobit) }\end{array}$ & Females & $\begin{array}{l}\text { Mixed } \\
\text { (see text) }\end{array}$ & $\begin{array}{c}\text { Bachelor, } \\
\text { master } \\
\text { degree }\end{array}$ & $\begin{array}{c}\text { Not } \\
\text { working } \\
\text { full time }\end{array}$ & - & - & - & $\begin{array}{l}\text { Internat- } \\
\text { ional }\end{array}$ & Business \\
\hline $\begin{array}{l}\text { Borisenko } \\
(2018) \\
\text { Portugal }\end{array}$ & $\begin{array}{l}\text { See Table } 1 \text { for sample } \\
\text { summary } \\
\text { ( } \mathrm{I}=\text { in-person sample, } \mathrm{O}= \\
\text { online); univariate analysis }\end{array}$ & $\begin{array}{l}\text { Insig. in } \\
\text { both } \\
\text { samples }\end{array}$ & $\begin{array}{c}\text { I: age }<45 \\
\text { O: insig. }\end{array}$ & $\begin{array}{c}\text { I: } \\
\text { Bachelor } \\
\text { degree } \\
\text { O: insig. }\end{array}$ & $\begin{array}{l}\text { I: } \\
\text { employed } \\
\text { or student } \\
\text { O: insig. }\end{array}$ & - & - & - & - & - \\
\hline
\end{tabular}




\begin{tabular}{|c|c|c|c|c|c|c|c|c|c|c|c|}
\hline & $\begin{array}{c}\text { Study Summary: } \\
\text { Location, Sample Type } \\
\text { and Size(s), Analysis } \\
\text { Technique }\end{array}$ & $\begin{array}{c}\text { Typical/ } \\
\text { Previous } \\
\text { Hotel } \\
\text { Type }\end{array}$ & Comfort & Luxury & $\begin{array}{l}\text { Green } \\
\text { as Cost } \\
\text { Cutting }\end{array}$ & $\begin{array}{l}\text { Overall } \\
\text { Image of } \\
\text { (Green) } \\
\text { Hotels }\end{array}$ & Eco Awareness & Eco Beliefs & $\begin{array}{c}\text { Eco } \\
\text { Attitudes }\end{array}$ & Eco Actions & $\begin{array}{c}\text { Personality } \\
\text { Traits }\end{array}$ \\
\hline $\begin{array}{l}\text { Fairweather, } \\
\text { Maslin \& } \\
\text { Simmons } \\
(2005)^{*} \\
\end{array}$ & $\begin{array}{l}\text { See Table } 1 \text { for sample } \\
\text { summary; cluster } \\
\text { analysis }\end{array}$ & - & - & - & - & - & - & - & $\begin{array}{l}\text { Biocentric } \\
\text { respondents }\end{array}$ & - & - \\
\hline $\begin{array}{l}\text { Choi et al. } \\
(2009)^{*}\end{array}$ & $\begin{array}{l}\text { See Table } 1 \text { for sample } \\
\text { summary; multinomial } \\
\text { logistic regression }\end{array}$ & - & - & - & - & - & - & - & Insig. & $\begin{array}{l}\text { Behaviourial } \\
\text { intentions } \\
\text { regarding } \\
\text { organization } \\
\text { al and } \\
\text { operation } \\
\text { green } \\
\text { practices } \\
\end{array}$ & - \\
\hline $\begin{array}{l}\text { Han et al. } \\
(2009)^{*}\end{array}$ & $\begin{array}{l}\text { USA; online survey of } \\
\text { general hotel customers; } \\
n=371 \text {; SEM }\end{array}$ & - & - & - & - & Positive & - & - & - & - & - \\
\hline $\begin{array}{l}\text { Lee et al. } \\
\text { (2010)* }\end{array}$ & $\begin{array}{l}\text { USA; online survey of } \\
\text { green hotel customers; } n \\
=416 ; \text { SEM }\end{array}$ & - & - & - & - & Positive & - & - & - & - & - \\
\hline $\begin{array}{l}\text { Han et al. } \\
(2011)^{*}\end{array}$ & $\begin{array}{l}\text { USA; online survey of } \\
\text { general hotel customers; } \\
\mathrm{n}=422 ; \text { analysis of } \\
\text { variance, multiple } \\
\text { regression analysis }\end{array}$ & $\begin{array}{l}\text { Prior stay } \\
\text { at a green } \\
\text { hotel }\end{array}$ & - & - & - & - & - & - & $\begin{array}{l}\text { Mixed } \\
\text { results (see } \\
\text { text for } \\
\text { more } \\
\text { details) }\end{array}$ & - & - \\
\hline $\begin{array}{l}\text { Tsagarakis et } \\
\text { al. (2011)* }\end{array}$ & $\begin{array}{l}\text { See Table } 1 \text { for sample } \\
\text { summary; binary } \\
\text { logistic regression; ESI } \\
\text { indicates hotels with } \\
\text { energy saving } \\
\text { installations, RES hotels } \\
\text { with renewable energy } \\
\text { sources }\end{array}$ & - & - & - & - & - & $\begin{array}{l}\text { ESI: well and little } \\
\text { informed on energy } \\
\text { saving } \\
\text { RES: well informed on } \\
\text { renewable energy } \\
\text { ESI and RES: from a } \\
\text { country with very high } \\
\text { energy awareness }\end{array}$ & $\begin{array}{l}\text { ESI: believe } \\
\text { climate } \\
\text { change } \\
\text { related to } \\
\text { use fossil } \\
\text { fuels } \\
\text { ESI and } \\
\text { RES: } \\
\text { believe } \\
\text { climate } \\
\text { change can } \\
\text { be mitigated } \\
\text { with RES, } \\
\text { believe } \\
\text { energy } \\
\text { savings } \\
\text { should } \\
\text { precede } \\
\text { increasing }\end{array}$ & - & $\begin{array}{c}\text { ESI: use } \\
\text { econony } \\
\text { programs for } \\
\text { (dish)washer } \\
\text {, close } \\
\text { doors/windo } \\
\text { ws when } \\
\text { heat/cool on } \\
\text { at home, } \\
\text { don't leave } \\
\text { appliances } \\
\text { on stand-by } \\
\text { mode at } \\
\text { home } \\
\text { ESI and } \\
\text { RES: make } \\
\text { rational use } \\
\text { of air } \\
\text { conditioner }\end{array}$ & - \\
\hline
\end{tabular}




\begin{tabular}{|c|c|c|c|c|c|c|c|c|c|c|c|}
\hline & & & & & & & & $\begin{array}{c}\text { energy } \\
\text { production }\end{array}$ & & $\begin{array}{l}\text { at home, } \\
\text { only turn on } \\
\text { hotel lights } \\
\text { when } \\
\text { necessary } \\
\end{array}$ & \\
\hline $\begin{array}{l}\text { Kang et al. } \\
(2012)^{*}\end{array}$ & $\begin{array}{l}\text { See Table } 1 \text { for sample } \\
\text { summary; } U \text { indicates } \\
\text { univariate analysis, } M \\
\text { multiple regression } \\
\text { analysis }\end{array}$ & $\begin{array}{c}\text { U: } \\
\text { typically } \\
\text { stays at } \\
\text { luxury } \\
\text { M: mid- } \\
\text { range and } \\
\text { luxury }\end{array}$ & - & - & - & - & - & - & $\begin{array}{l}\text { U: higher } \\
\text { NEP score } \\
\text { M: higher } \\
\text { NEP score }\end{array}$ & - & - \\
\hline $\begin{array}{l}\text { Baker, Davis } \\
\& \text { Weaver } \\
(2014)^{*}\end{array}$ & $\begin{array}{c}\text { US; online survey of } \\
\text { hotel customers; } \mathrm{n}= \\
\text { 208; multiple regression } \\
\text { analysis }\end{array}$ & - & Neg. & Insig. & Neg. & - & - & - & $\begin{array}{l}\text { Mixed } \\
\text { results (see } \\
\text { text for } \\
\text { more } \\
\text { details) }\end{array}$ & - & - \\
\hline $\begin{array}{l}\text { Dimara et al. } \\
\text { (2015) }\end{array}$ & $\begin{array}{l}\text { See Table } 1 \text { for sample } \\
\text { summary; univariate } \\
\text { analysis }\end{array}$ & Insig. & - & - & - & - & - & - & - & - & \\
\hline $\begin{array}{l}\text { Rahman \& } \\
\text { Reynolds } \\
(2016)^{*}\end{array}$ & $\begin{array}{l}\text { USA; online sample } \\
\text { using Amazon's } \\
\text { Mechanical Turk; } n= \\
\text { 372; SEM } \\
\end{array}$ & - & - & - & - & - & - & - & $\begin{array}{l}\text { Willingness } \\
\text { to sacrifice } \\
\text { for the } \\
\text { environment }\end{array}$ & - & \\
\hline $\begin{array}{l}\text { Tang \& Lam } \\
\text { (2016) }\end{array}$ & $\begin{array}{c}\text { Macao, China; } \\
\text { Generation Y } \\
\text { consumers (university } \\
\text { students and resort } \\
\text { employees); } \mathrm{n}=406 ; \\
\text { SEM } \\
\end{array}$ & - & - & - & - & - & - & - & Positive & - & $\begin{array}{c}\text { Extraversion } \\
\text { and } \\
\text { agreeablenes } \\
\text { s }\end{array}$ \\
\hline $\begin{array}{l}\text { Nyström } \\
\text { (2017) }\end{array}$ & $\begin{array}{l}\text { See Table } 1 \text { for sample } \\
\text { summary; regression } \\
\text { (Cragg's Tobit) }\end{array}$ & $\begin{array}{l}\text { Mixed } \\
\text { (see text) }\end{array}$ & - & - & - & - & - & - & $\begin{array}{c}\text { Prioritise } \\
\text { environment } \\
\text { al protection } \\
\text { same/more } \\
\text { than } \\
\text { economic } \\
\text { growth } \\
\end{array}$ & - & - \\
\hline
\end{tabular}


* variables indicated were significantly (i.e., at 0.05 or better) associated with a willingness to pay a premium to stay at a green hotel; insig. = insignificant; neg. = negative; $\mathrm{SEM}=$ structural equation modelling

Table 2. Explanators of WTP for Green Lodging

Method

An online survey was conducted via a panel operated by a leading US market research company. A screening question was employed to allow only participants who had spent one or more nights in a commercial lodging facility in the previous two years; only respondents aged 18 or over were recruited. Since the survey represented one part of a broader study that compared consumer opinion and industry practice, only residents of the US state of Michigan were invited to respond. All ethical protocols were complied with, participation was completely voluntary, and no incentives were offered. A total of 388 usable responses were received.

\section{Measurement}

The survey instrument was divided into five sections, focusing on: (i) attitudes towards the environment; (ii) general environmental behaviour; (iii) environmental behavior when travelling; (iv) attitudes towards environmental practices at lodging facilities, including WTP; and (v) socioeconomic, demographic and travel characteristics. Items from sections i, iv and $\mathrm{v}$ are reported here.

Environmental attitudes were measured using the revised New Environmental Paradigm (NEP) scale. This set of items was originally developed by Dunlap and Van Liere in 1978 and later revised by Dunlap, Van Liere, Mertig and Jones (2000). The 15-item scale incorporates five components of an ecological worldview: the reality of limits to growth, antianthropocentrism, fragility of nature's balance, rejection of exceptionalism, and possibility of an eco-crisis (see Table 3). Respondents rated their (dis)agreement with the fifteen items on a 
Likert scale where 1 indicated strong disagreement and 5 strong agreement. Given the wording of the items (eight of which measure pro-ecological viewpoints whilst the other seven measure attitudes not supportive of concern for the environment), responses to the latter items were reverse coded prior to calculation of each respondent's overall environmental score. The NEP has been successfully used in various tourism contexts, e.g., as a basis for market segmentation (e.g., Zografos \& Allcroff, 2007), as a determinant of backpackers' trip purchasing behaviours (Wearing, Cynn, Ponting \& McDonald, 2002), and in relation to nature-based motivations (Luo \& Deng, 2008).

1. We are approaching the limit of the number of people the earth can support.

2. Humans have the right to modify the natural environment to suit their needs.

3. When humans interfere with nature it often produces disastrous consequences.

4. Human ingenuity will insure that we do not make the earth unlivable.

5. Humans are severely abusing the earth.

6. The earth has plenty of natural resources if we just learn how to develop them.

7. Plants and animals have as much right as humans to exist.

8. The balance of nature is strong enough to cope with the impacts of modern industrial nations.

9. Despite our special abilities, humans are still subject to the laws of nature.

10. The so-called "ecological crisis" facing humankind has been greatly exaggerated.

11. The earth is like a spaceship with very limited room and resources.

12. Humans were meant to rule over the rest of nature.

13. The balance of nature is very delicate and easily upset.

14. Humans will eventually learn enough about how nature works to be able to control it.

15. If things continue on their present course, we will soon experience a major environmental catastrophe.

Table 3. Revised NEP Items (Dunlap et al., 2000)

WTP was established based on the question, "Imagine that you are typically willing to spend \$100 on a hotel room per night. How much would you be willing to spend on a room per night at a 'green' lodging facility?" Allowable responses included "less than the typical $\$ 100, "$, \$100," or "greater than the typical \$100." The notion of "green lodging" was defined for respondents per the Michigan Department of Environmental Quality and Energy Office, 
as "a term used to characterize hotels, motels, resorts and bed \& breakfasts who are leaders in energy conservation, air quality, and reduced water consumption and waste."

Socioeconomic and demographic questions included those pertaining to age, gender, education, employment situation, and income. Respondents were also asked to indicate the type of area they live in (urban, suburban, rural) and their typical travel patterns in terms of frequency of hotel-based travel and type of property most commonly stayed in (luxury, midrange, economy).

Analysis

Descriptive statistics were first calculated for all variables. Differences in average NEP scores between those willing and those not willing to pay more for a green room were calculated using $t$-tests. After assessment of the internal consistency of the NEP scores, principal component analysis (PCA) was conducted to reduce the data into a smaller number of factors. Finally, logistic regression was employed to identify significant influences on willingness to spend less/more than the norm for a green room. Regressions were run using both the average NEP scores and the subscales identified in the PCA.

\section{Findings}

Characteristics of the respondents are shown in Table 4. Respondents were predominantly female and were most likely to hold a high school diploma or Associate's degree and earn less than $\$ 75,000$. They were most likely to live in a suburban setting and frequent mid-range lodging properties. 


\begin{tabular}{|c|c|c|}
\hline Characteristic & $n$ & $\%$ \\
\hline \multicolumn{3}{|l|}{ Gender } \\
\hline Male & 82 & 21.1 \\
\hline Female & 306 & 78.9 \\
\hline \multicolumn{3}{|l|}{ Education level } \\
\hline Less than high school & 5 & 1.3 \\
\hline High school & 154 & 39.7 \\
\hline $\begin{array}{l}\text { Associate's degree or } \\
\text { equivalent ( } 2 \text { year college })\end{array}$ & 103 & 26.5 \\
\hline $\begin{array}{l}\text { Bachelor's degree or } \\
\text { equivalent ( } 4 \text { year college) }\end{array}$ & 86 & 22.2 \\
\hline Postgraduate degree & 40 & 10.3 \\
\hline \multicolumn{3}{|l|}{ Employment situation } \\
\hline I am employed full time & 168 & 43.3 \\
\hline I am employed part time & 60 & 15.5 \\
\hline I am a home maker & 59 & 15.2 \\
\hline I am retired & 58 & 14.9 \\
\hline I am a student & 16 & 4.1 \\
\hline I am currently unemployed & 27 & 7.0 \\
\hline \multicolumn{3}{|l|}{ Age } \\
\hline $18-24$ & 44 & 11.3 \\
\hline $25-34$ & 106 & 27.3 \\
\hline $35-44$ & 66 & 17.0 \\
\hline $45-54$ & 72 & 18.6 \\
\hline $55-64$ & 59 & 15.2 \\
\hline $65-74$ & 36 & 9.3 \\
\hline $75-84$ & 5 & 1.3 \\
\hline \multicolumn{3}{|l|}{ Household income } \\
\hline Less than $\$ 25,000$ & 91 & 23.5 \\
\hline$\$ 25,000-\$ 49,999$ & 120 & 30.9 \\
\hline$\$ 50,000-\$ 74,999$ & 92 & 23.7 \\
\hline$\$ 75,000-\$ 99,999$ & 32 & 8.2 \\
\hline$\$ 100,000$ or more & 53 & 13.7 \\
\hline \multicolumn{3}{|l|}{ Type of area lived in } \\
\hline Urban & 71 & 18.3 \\
\hline Suburban & 203 & 52.3 \\
\hline Rural & 114 & 29.4 \\
\hline \multicolumn{3}{|c|}{ Frequency of hotel-based travel } \\
\hline One or less & 149 & 38.4 \\
\hline Two to three & 107 & 27.6 \\
\hline Four to five & 49 & 12.6 \\
\hline Six to seven & 33 & 8.5 \\
\hline Eight or more & 50 & 12.9 \\
\hline \multicolumn{3}{|l|}{ Type of property } \\
\hline Luxury hotel & 29 & 7.5 \\
\hline Mid-range hotel/motel & 215 & 55.4 \\
\hline Economy hotel/motel & 120 & 30.9 \\
\hline $\mathrm{B} \& \mathrm{~B} / \mathrm{inn}$ & 12 & 3.1 \\
\hline Other & 12 & 3.1 \\
\hline
\end{tabular}


Table 4. Respondent Characteristics ( $\mathrm{n}=388$ for all items)

Of the 388 respondents, $44.3 \%$ indicated that they would be willing to spend more than the typical $\$ 100$ on a room at a "green" lodging facility, $38.1 \%$ would pay the typical $\$ 100$, and $17.6 \%$ less than $\$ 100$. The remaining analysis focuses only on those willing to pay more $(n=171)$ or less $(n=68)$. Significant differences $(p<0.05)$ in NEP scores between these two groups were indicated for twelve of the fifteen NEP items; as expected, those willing to spend more for a green room indicated a higher level of environmental concern in all of those cases (Table 5).

\begin{tabular}{|c|c|c|c|c|}
\hline & & $M$ & $S D$ & $t$ \\
\hline \multirow{2}{*}{$\begin{array}{l}\text { 1. We are approaching the limit of the number of } \\
\text { people the earth can support. }\end{array}$} & $\mathrm{L}$ & 2.99 & 1.41 & \multirow{2}{*}{$-2.75 * *$} \\
\hline & $\mathrm{G}$ & 3.48 & 1.19 & \\
\hline \multirow{2}{*}{$\begin{array}{l}\text { 2. Humans have the right to modify the natural } \\
\text { environment to suit their needs. }\end{array}$} & $\mathrm{L}$ & 3.03 & 1.38 & \multirow{2}{*}{$-3.18 * *$} \\
\hline & G & 3.60 & 1.20 & \\
\hline \multirow{4}{*}{$\begin{array}{l}\text { 3. When humans interfere with nature, it often } \\
\text { produces disastrous consequences. } \\
\text { 4. Human ingenuity will ensure that we do not make } \\
\text { the earth unlivable. }\end{array}$} & $\mathrm{L}$ & 3.94 & 1.27 & \multirow{2}{*}{-1.59} \\
\hline & $\mathrm{G}$ & 4.19 & 1.03 & \\
\hline & $\mathrm{L}$ & 2.65 & 1.14 & \multirow{2}{*}{-0.97} \\
\hline & $\mathrm{G}$ & 2.81 & 1.14 & \\
\hline \multirow{2}{*}{ 5. Humans are severely abusing the earth. ${ }^{a}$} & $\mathrm{~L}$ & 3.74 & 1.34 & \multirow{2}{*}{$-3.54 * * *$} \\
\hline & $\mathrm{G}$ & 4.36 & 0.90 & \\
\hline \multirow{4}{*}{$\begin{array}{l}\text { 6. The earth has plenty of natural resources if we just } \\
\text { learn how to develop them. } \\
\text { 7. Plants and animals have as much right as humans } \\
\text { to exist. }^{\text {a }}\end{array}$} & $\mathrm{L}$ & 2.09 & 1.29 & \multirow{2}{*}{-0.54} \\
\hline & $\mathrm{G}$ & 2.18 & 1.15 & \\
\hline & $\mathrm{L}$ & 3.96 & 1.30 & \multirow{2}{*}{$-3.44 * * *$} \\
\hline & $\mathrm{G}$ & 4.53 & 0.75 & \\
\hline 8. The balance of nature is strong enough to cope & $\mathrm{L}$ & 3.16 & 1.29 & \multirow{2}{*}{$-2.39 *$} \\
\hline with the impacts of modern industrial nations. & $\mathrm{G}$ & 3.59 & 1.23 & \\
\hline 9. Despite our special abilities, humans are still & $\mathrm{L}$ & 4.16 & 0.94 & \multirow{2}{*}{$-2.13 *$} \\
\hline subject to the laws of nature. & $\mathrm{G}$ & 4.42 & 0.81 & \\
\hline 10. The so-called "ecological crisis" facing & $\mathrm{L}$ & 2.93 & 1.45 & \multirow{2}{*}{$-4.75^{* * *}$} \\
\hline humankind has been greatly exaggerated. ${ }^{a}$ & $\mathrm{G}$ & 3.87 & 1.18 & \\
\hline \multirow{2}{*}{$\begin{array}{l}11 . \text { The earth is like a spaceship with very limited } \\
\text { room and resources. }\end{array}$} & $\mathrm{L}$ & 3.22 & 1.23 & \multirow{2}{*}{$-2.44 *$} \\
\hline & $\mathrm{G}$ & 3.64 & 1.18 & \\
\hline \multirow{4}{*}{$\begin{array}{l}\text { 12. Humans were meant to rule over the rest of } \\
\text { nature. } \\
\text { 13. The balance of nature is very delicate and easily } \\
\text { upset. }^{\text {a }}\end{array}$} & $\mathrm{L}$ & 3.01 & 1.42 & \multirow{2}{*}{$-3.13 * *$} \\
\hline & $\mathrm{G}$ & 3.63 & 1.34 & \\
\hline & $\mathrm{L}$ & 3.78 & 1.21 & \multirow{2}{*}{-1.77} \\
\hline & $\mathrm{G}$ & 4.07 & 0.96 & \\
\hline \multirow{3}{*}{$\begin{array}{l}\text { 14. Humans will eventually learn enough about how } \\
\text { nature works to be able to control it. }\end{array}$} & $\mathrm{L}$ & 2.91 & 1.25 & \multirow{2}{*}{$-2.21^{*}$} \\
\hline & $\mathrm{G}$ & 3.29 & 1.18 & \\
\hline & $\mathrm{L}$ & 3.82 & 1.24 & $-2.34 *$ \\
\hline
\end{tabular}




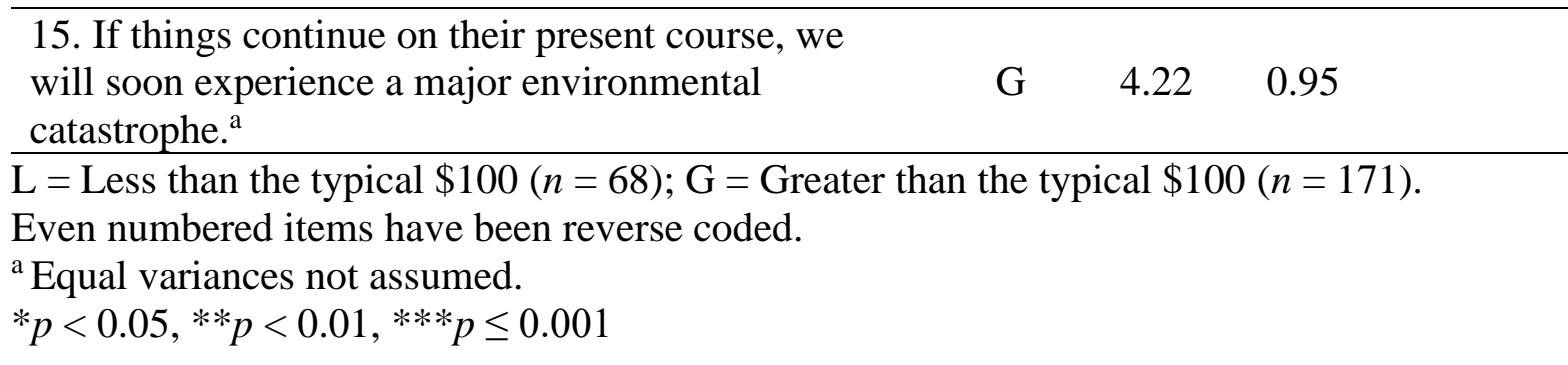

Table 5. Average NEP Scores by Willingness to Pay Less/More for a Green Hotel Room

Internal consistency of the 15 NEP items was assessed based on the corrected itemtotal correlation and Cronbach's alpha of each. All but two corrected item-total correlations were reasonably strong, ranging from 0.269 to 0.592 (for item $6=0.146$ and item $9=0.200$ ). Correlations less than 0.30 warrant consideration for deletion (Nunnally, 1967), though assessment of the Cronbach's Alpha's with deletion of each item can justify the maintaining of borderline items. In this case, removal of those two items with the lowest corrected itemtotal correlations was found to lead to a small improvement in internal consistency. The resulting set of 13 items demonstrated a Cronbach's alpha of 0.820 , suggesting a good level of internal consistency within the measurement instrument.

PCA saw the 13 remaining NEP items load on three factors, labelled eco-crisis, humans over nature, and limits to growth (after Luo \& Deng, 2008). These three factors together explained $57.6 \%$ of the total variance (eco-crisis, $23.3 \%$; humans over nature, $21.6 \%$; limits to growth, $12.7 \%$ ). The Kaiser-Meyer-Olkin (KMO) measure of sampling adequacy was 0.837 and Bartlett's test of sphericity was significant $\left(\chi^{2}(78)=968.214, \mathrm{p}<\right.$ 0.001) (Table 6). 


\begin{tabular}{|c|c|c|c|}
\hline \multirow{2}{*}{ Factors and items } & \multicolumn{3}{|c|}{ Rotated (Varimax) factors } \\
\hline & Factor 1 & Factor 2 & Factor 3 \\
\hline \multicolumn{4}{|l|}{ Factor 1: Eco-Crisis } \\
\hline NEP 7 (Anti-Anthro) & 0.776 & & \\
\hline NEP 5 (Eco-Crisis) & 0.738 & & \\
\hline NEP 13 (Balance) & 0.703 & & \\
\hline NEP 15 (Eco-Crisis) & 0.679 & & \\
\hline NEP 3 (Balance) & 0.644 & & \\
\hline \multicolumn{4}{|l|}{ Factor 2: Humans over nature } \\
\hline NEP 8 (Balance) & & 0.775 & \\
\hline NEP 14 (Anti-Exempt) & & 0.686 & \\
\hline NEP 10 (Eco-Crisis) & & 0.676 & \\
\hline NEP 2 (Anti-Anthro) & & 0.672 & \\
\hline NEP 12 (Anti-Anthro) & & 0.607 & \\
\hline NEP 4 (Anti-Exempt) & & 0.604 & \\
\hline \multicolumn{4}{|l|}{ Factor 3: Limit to growth } \\
\hline NEP 11 (Limits) & & & 0.831 \\
\hline NEP 1 (Limits) & & & 0.801 \\
\hline Eigenvalues & 3.029 & 2.812 & 1.648 \\
\hline$\%$ of variance & 23.296 & 21.628 & 12.679 \\
\hline Cumulative \% & 23.296 & 44.924 & 57.604 \\
\hline Standardized Cronbach's Alpha & 0.805 & 0.749 & 0.709 \\
\hline
\end{tabular}

Note: Loadings of 0.6 and above are presented.

Table 6. New ecological paradigm factor loadings and subscales

Regression based on average NEP scores found that two variables - average NEP scores and household income - had a significant positive impact on WTP. The odds ratios $(\operatorname{Exp}(B))$ of these two variables may be interpreted as follows: for every one-unit increase in NEP score, a $356.0 \%$ increase in the log-odds of WTP a premium is expected, holding all other independent variables constant; and, for every one-unit increase in the level of annual house income, a $33.8 \%$ increase in the log-odds of WTP a premium is expected.

Though not particularly impressive, the Nagelkerke $\mathrm{R}^{2}$ of 0.233 compares adequately with the equivalent measures of model fit employed in previous studies, e.g., adjusted $\mathrm{R}^{2}$ of 0.14 in Kang et al. (2012). As has often been found in previous analyses, none of the other socioeconomic, demographic or travel pattern variables produced any significant impacts on WTP (Table 7). 


\begin{tabular}{lcccccc}
\hline Variables & $B$ & $S E$ & Wald & df & Sig. & $\operatorname{Exp}(B)$ \\
\hline Constant & -5.743 & 1.528 & 14.132 & 1 & $0.000^{* * *}$ & 0.003 \\
$\begin{array}{l}\text { Average NEP } \\
\text { scores }\end{array}$ & 1.517 & 0.294 & 26.586 & 1 & $0.000^{* * * *}$ & 4.560 \\
Urban & -0.441 & 0.492 & 0.804 & 1 & 0.370 & 0.643 \\
$\begin{array}{l}\text { Suburban } \\
\text { Male }\end{array}$ & 0.128 & 0.396 & 0.105 & 1 & 0.746 & 1.137 \\
$\begin{array}{l}\text { Employed full time } \\
\text { Employed part }\end{array}$ & -0.018 & 0.415 & 0.002 & 1 & 0.965 & 0.982 \\
time & -0.240 & 0.510 & 0.221 & 1 & 0.638 & 0.787 \\
$\begin{array}{l}\text { Homemaker } \\
\text { Frequency of hotel- }\end{array}$ & 0.188 & 0.522 & 0.130 & 1 & 0.719 & 1.207 \\
based travel & 0.174 & 0.137 & 1.607 & 1 & 0.205 & 1.190 \\
$\begin{array}{l}\text { Mid-range } \\
\text { hotel/motel }\end{array}$ & 0.122 & 0.714 & 0.029 & 1 & 0.864 & 1.130 \\
$\begin{array}{l}\text { Luxury hotel } \\
\text { Economy }\end{array}$ & 0.707 & 0.908 & 0.607 & 1 & 0.436 & 2.028 \\
hotel/motel & 0.073 & 0.744 & 0.010 & 1 & 0.922 & 1.076 \\
$\begin{array}{l}\text { Age } \\
\text { Household income }\end{array}$ & -0.026 & 0.110 & 0.056 & 1 & 0.813 & 0.974 \\
\hline $\mathrm{n}=239$ & & & & 1 & $0.044 *$ & 1.338 \\
\hline
\end{tabular}

Dependent variable $=$ two groups in willingness to spend (i.e., less than the typical $\$ 100$ and greater than the typical $\$ 100$ )

-2 Log likelihood $=243.155$, Cox \& Snell $R^{2}=0.162$, Nagelkerke $R^{2}=0.233$.

$* p<0.05, * * p<0.01, * * * p<0.001$

Table 7. Regression results (average NEP scores)

Regression based on the three factors identified by the PCA revealed that two of the three were significantly associated with willingness to spend more for a green hotel room; the relationship between WTP and household income remained significant. The odds ratios $(\operatorname{Exp}(B))$ of these three variables may be interpreted as follows: for every one-unit increase in Factor 1: Eco-Crisis, a 73.3\% increase in the log-odds of WTP a premium is expected, holding all other independent variables constant; for every one-unit increase in Factor 2: Humans over Nature, a 95.0\% increase in the log-odds of WTP a premium is expected; and, for every one-unit increase in the level of annual house income, a 32.8\% increase in the logodds of WTP a premium is expected.

The limits to growth factor (including the two items 'We are approaching the limit of the number of people the earth can support' and 'The earth is like a spaceship with very 
limited room and resources') was insignificant in this model, as were all other socioeconomic, demographic and travel-related variables. Nagelkerke $\mathrm{R}^{2}$ declined slightly, to 0.228 (Table 8).

\begin{tabular}{|c|c|c|c|c|c|c|}
\hline Variables & $B$ & $S E$ & Wald & $\mathrm{df}$ & Sig. & $\operatorname{Exp}(B)$ \\
\hline Constant & -0.174 & 0.943 & 0.034 & 1 & 0.853 & 0.840 \\
\hline $\begin{array}{l}\text { Factor 1: Eco- } \\
\text { Crisis }\end{array}$ & 0.550 & 0.158 & 12.128 & 1 & $0.000 * * *$ & 1.733 \\
\hline $\begin{array}{l}\text { Factor 2: } \\
\text { Humans over } \\
\text { nature }\end{array}$ & 0.668 & 0.171 & 15.223 & 1 & $0.000 * * *$ & 1.950 \\
\hline $\begin{array}{l}\text { Factor 3: Limit } \\
\text { to growth }\end{array}$ & 0.249 & 0.163 & 2.344 & 1 & 0.126 & 1.283 \\
\hline Urban & -0.423 & 0.492 & 0.739 & 1 & 0.390 & 0.655 \\
\hline Suburban & 0.125 & 0.401 & 0.097 & 1 & 0.755 & 1.133 \\
\hline Male & -0.024 & 0.415 & 0.003 & 1 & 0.954 & 0.976 \\
\hline $\begin{array}{l}\text { Employed full } \\
\text { time }\end{array}$ & 0.566 & 0.444 & 1.623 & 1 & 0.203 & 1.761 \\
\hline $\begin{array}{l}\text { Employed part } \\
\text { time }\end{array}$ & -0.249 & 0.510 & 0.237 & 1 & 0.626 & 0.780 \\
\hline Homemaker & 0.184 & 0.520 & 0.125 & 1 & 0.724 & 1.202 \\
\hline $\begin{array}{l}\text { Frequency of } \\
\text { hotel-based } \\
\text { travel }\end{array}$ & 0.159 & 0.136 & 1.376 & 1 & 0.241 & 1.173 \\
\hline $\begin{array}{l}\text { Mid-range } \\
\text { hotel/motel }\end{array}$ & 0.016 & 0.725 & 0.000 & 1 & 0.983 & 1.016 \\
\hline Luxury hotel & 0.630 & 0.911 & 0.478 & 1 & 0.489 & 1.878 \\
\hline $\begin{array}{l}\text { Economy } \\
\text { hotel/motel }\end{array}$ & -0.010 & 0.752 & 0.000 & 1 & 0.989 & 0.990 \\
\hline Age & -0.019 & 0.110 & 0.029 & 1 & 0.866 & 0.982 \\
\hline $\begin{array}{l}\text { Household } \\
\text { income }\end{array}$ & 0.284 & 0.145 & 3.831 & 1 & $0.050 *$ & 1.328 \\
\hline
\end{tabular}

Dependent variable $=$ two groups in willingness to spend (i.e., less than the typical $\$ 100$ and greater than the typical $\$ 100$ )

-2 Log likelihood $=243.988$, Cox \& Snell $R^{2}=0.159$, Nagelkerke $R^{2}=0.228$.

${ }^{*} p<0.05, * * p<0.01, * * * p<0.001$

Table 8. Regression results (NEP subscales) 
Discussion, Limitations and Future Research

The findings confirm those of Kang et al. (2012) with respect to the positive relationship between environmental concern and WTP for a green hotel. However, findings were opposite to theirs with respect to the influence of income and property type. While the Kang study found the former variable to have a negative influence of WTP, it was positive here. In contrast, while the tendency to frequent mid-range or luxury properties had positive impacts on WTP a green room premium according to Kang et al., those two variables were insignificant in this study. Findings of significant relationships between basic socioeconomic/demographic variables and WTP for green initiatives have important implications for the implementation and marketing of green initiatives by the lodging sector; unfortunately, however, the evidence to date remains inconclusive, suggesting the need for additional analysis across more, larger and more diverse samples. As noted by Luo and Deng (2008), greater consideration of social-psychological factors in addition to socio-demographic variables might also be instructive.

Though previous studies have reported differences in environmental concern, attitudes, and actions between residents of urban and rural areas (e.g., Berenguer, Corraliza, \& Martín, 2005), this study revealed no differences in WTP based on residence in an urban, suburban or rural setting. Similarly, neither frequency of travel nor type of property frequented (economy, mid or luxury) had any significant impact on WTP.

While the general relationship noted by Kang et al. (2012), of a positive relationship between environmental concern and WTP for a green hotel, was confirmed, more detailed analysis based on the three NEP subscales identified by PCA revealed that only two of those three reached significance. Whilst the findings do generally support social identity and means-end theory, the first time analysis of the NEP in terms of three subscales as conducted here nevertheless suggests a potential need to examine the dimensions of the NEP more 
carefully in future analyses; the need to consider the multidimensionality of the NEP scale in future work is an important contribution of this study.

The study focused on travellers within a single US state, and the generalisability of the findings beyond the US Midwest is unknown. Michigan has enjoyed considerable success with its Pure Michigan marketing campaign, with the brand becoming well-known within the state and a source of considerable pride for state residents. The impact of the environmentally friendly connotations of the campaign - whether on residents' or travellers' attitudes, intentions and/or behaviours - has not yet been investigated. Analysis of the spillover effects of both marketing campaigns - and of visits to/stays at green attractions/properties - on environmental attitudes, intentions and/or behaviours is an under-researched area worthy of future attention. Such work might draw on relevant theory from the (social) psychological realms including positive psychology and the concept of eudaimonia (e.g., Seligman \& Csikszentmihalyi, 2000). (Hunt \& Harbor, 2019). Qualitative assessment focusing on the adventure, wellness and eco-tourism (AWE) sector in Costa Rica, for example, has recently identified three key mechanisms that motivate travellers towards pro-environmental behaviour post-trip, namely immersive experiences, identity reinforcement, and meaningful reflection opportunities during and after the trip (Hunt \& Harbour, 2019), and those authors conclude by noting the need for further research to identify how the characteristics of AWE "can be further adapted, adopted, and scaled up to inspire pro-environmental behavior across the tourism industry more broadly" (p. 7).

Comparability of the findings with those of previous studies is somewhat stymied by variations in definition of 'green'/'greenness' and measurement of WTP. Some studies, such as this one, have looked at general WTP more or less than a specified amount; some have specified an actual amount or percentage more or less than some starting point; whilst others 
have left the amount open ended and asked respondents to fill that blank in. Greater consistency between studies would facilitate easier comparison across time and space.

The approach adopted focuses on travellers' intentions, in a hypothetical manner, rather than their actual behaviours, and as prior work has demonstrated the best behavioural intentions do not always translate into reality. Both attribution theory and cognitive dissonance theory have been proposed as perspectives from which to better understand the attitude-behaviour gap in sustainable tourism, and the use of in-house interventions has been proposed to precipitate behavioural change amongst hotel guests (e.g., Juvan \& Dolnicar, 2014). Future research could also include a greater focus on the analysis of travellers' observed payment patterns via a revealed preference approach. Hedonic pricing methodologies can be used to establish the determinants of observed hotel room prices across a range of settings and scales, while a mix of quantitative and qualitative approaches could be used to elicit greater understanding of the drivers of acceptance of pricing from a consumer perspective. Signaling theory could be used a framework via which to ascertain the role of green ratings or certification schemes in consumer choice (as noted by Sánchez-Pérez, Illescas-Manzano \& Martínez-Puertas, 2019) in the context of hotel categories and classifications). Additionally, choice modelling might be conducted to uncover how travellers value individual attributes of green lodging; attributes might include elements of provision, i.e., structural elements of green rooms and associated hotel services as well as of broader green hotel programming, and choices can be examined in the context of a wide range of individual determinants. Choice modelling can focus on revealed or stated preferences; though the latter approach is still hypothetical in nature, it nevertheless allows identification of the specific green practices that most appeal to consumers and for which they are mostly likely to pay a premium. 
An additional issue of relevance is the potential for continuing change in the way in which consumers view the notion of 'green' and in their willingness to adopt green practices, both at home and when they are travelling. What, for example, are travellers' perceptions as far as what has now become standard in the lodging sector (i.e., what is expected of all establishments as a core offering at no additional price) and what amenities or practices might they still be willing to pay more for? InterContinental Hotels Group, for example, recently announced that it will phase out the use of mini plastic toiletries in its 843,000 rooms by 2021, replacing them with bulk-size bottles of shampoo, conditioner, etc. (Adams, 2019). Or are travellers leaning instead towards the expectation that since the adoption of green practices offers providers the potential for monetary savings, properties should in fact be passing on those savings to their customers? Though recent research into energy practices among small- and medium-size tourism enterprises in the south west of England emphasises that the adoption of practices alone is not sufficient to stem the rising tide of energy consumption and associated costs (Coles, Dinan \& Warren, 2016). These questions tie into the problem of greenwashing, and consumers' abilities to see beyond any green veneers to truer implementation of meaningful green practices that benefit society and the environment in addition to the establishment's bottom line. It is therefore imperative to consider both supply and demand in a more holistic manner, in comparison to the tendency of research to date to focus on one or the other, since property owners' and managers' decisions are just as likely to be based on their perceptions of consumers' wants and needs - in the ever-present quest to enhance customer experiences - as they are by cost efficiencies.

The importance of the style of communication of sustainability benefits has also been identified, with the most appealing messages in a Dutch context being those that highlight personal benefit and that focus on injunctive and descriptive norms (Hardeman, Font \& Nawijn, 2017). Such findings highlight the need for further investigation of the motivations 
for pro-environmental behaviours in different settings, building on Miao and Wei's (2013) observation of the dominance of normative motives at home versus hedonic motives in the context of hotel accommodation. Taking an equity-based approach, Dolnicar, Cvelbar and Grün (2019) recently noted that "hotels, other tourism businesses as well as destinations wanting to trigger proenvironmental behavior in tourists should replace traditional appeals with messages that signal equity, fairness, or sharing of benefits between customer and provider" (Dolnicar et al., 2019, p. 249). The use of incentives to motivate participation in green practices at lodging properties - whether monetary or in the form of other sorts of activity- or loyalty-based rewards, e.g., discounts or rebates on current or future stays, or points that can be applied towards alternative amenities, in exchange for green choices such as not requesting clean linens or towels - is also worthy of investigation.

The influence of destination type and image on pro-environmental behavior have also recently been identified (Line \& Hanks, 2016; Line, Hanks \& Miao, 2018), and further analysis of these factors as intervening variables in the relationship between tourists' attitude toward the environment and their WTP for a green travel experience is warranted. In all cases a longitudinal approach is desirable, to help us move beyond the traditional snapshot approach and towards a better understanding of any changes in public attitudes towards the environment that might be occurring amongst consumers in light of increasing levels of public protest around climate change and the ongoing media coverage thereof.

\section{Conclusion}

As Richard Butler has so candidly noted, "Quite frankly, sustainable tourism is impossible, and we should focus on making operations more sustainable and acknowledge that tourism is an industry that deep down is impossible to make sustainable" (Sustainability Leaders Project, 2016). The drive for more realistic understandings of sustainability amongst 
researchers, providers and consumers, and the search for initiatives that can make genuine contributions to sustainability targets without compromising the bottom line, remain critical within the tourism and hospitality sectors. Studies such as this can continue to contribute to the quest for greater environmental friendliness by delivering evidence regarding consumer willingness to pay for lodging that respects the environment.

\section{References}

1. Adams, C. (2019, July 30). Hotel Group to Remove 200 Million Mini Plastic Toiletries in Next Two Years. The Independent. https://www.independent.co.uk/travel/news-andadvice/plastic-toiletries-intercontinental-hotels-bathroom-waste-removal-a9026636.html

2. Ajzen, I. (1991). The theory of planned behavior. Organizational Behavior and Human Decision Processes, 50(2), 179-211.

3. Baker, M., Davis, E. A., \& Weaver, P. A. (2014). Eco-friendly attitudes, barriers to participation, and differences in behavior at green hotels. Cornell Hospitality Quarterly, 55(1), 89-99.

4. Berenguer, J., Corraliza, J. A., \& Martín, R. (2005). Rural-urban differences in environmental concern, attitudes, and actions. European Journal of Psychological Assessment, 21(2), 128-138.

5. Borisenko, S. (2018). Tourists' willingness to pay for green hotel practices. Dissertation. Polytechnic Institute of Leiria.

6. Chang, L., Hsiao, Y., Nuryyev, G. and Huang, M. (2015) People's motivation, constraints and willingness to pay for green hotels. European Journal of Tourism Research, 9, 67-77.

7. Chia-Jung, C. \& Pei-Chun, C. (2014) Preferences and willingness to pay for green hotel attributes in tourist choice behavior: The case of Taiwan, Journal of Travel \& Tourism Marketing, 31:8, 937-957, DOI: 10.1080/10548408.2014.895479.

8. Coles, T. Dinan, C., \& Warren, N. (2016). Energy practices among small- and mediumsized tourism enterprises: a case of misdirected effort?, Journal of Cleaner Production, 111, Part B, 399-408.

9. Cone Communications (2017). 2017 Cone Communications CSR Study. Boston, MA.

10. Dolnicar, S., \& Leisch, F. (2008a). An investigation of tourists' pattern of obligation to protect the environment. Journal of Travel Research, 46, 381-391.

11. Dolnicar, S., \& Leisch, F. (2008b). Selective marketing for environmentally sustainable tourism. Tourism Management, 29, 672-680. 
12. Dolnicar, S., Cvelbar, L. K., \& Grün, B. (2019). A sharing-based approach to enticing tourists to behave more environmentally friendly. Journal of Travel Research, 58(2), 241252.

13. Dunlap, R.E., Van Liere, K.D., Mertig, A.G., \& Jones, R.E. (2000). Measuring endorsement of the new ecological paradigm: A revised NEP scale. Journal of Social Issues, 56(3), 425-442.

14. El Dief, M., \& Font, X. (2010). The determinants of hotels' marketing managers' green marketing behaviour, Journal of Sustainable Tourism, 18:2, 157-174, DOI:

10.1080/09669580903464232

15. Formica, S., \& Uysal, M. (2002). Segmentation of Travelers Based on Environmental Attitudes. Journal of Hospitality \& Leisure Marketing, 9, 35-49. DOI: 10.1300/J150v09n03_04.

16. Gao, Y., Mattila, A., \& Lee, S. (2016). A meta-analysis of behavioral intentions for environment-friendly initiatives in hospitality research. International Journal of Hospitality Management, 54, 107-115. DOI: 10.1016/j.ijhm.2016.01.010.

17. Gutman, J. (1982). A means-end chain model based on consumer categorization processes. Journal of Marketing, 46(2), 60-72.

18. Han, X., \& Chan, K. (2013) Perception of green hotels among tourists in Hong Kong: An exploratory study. Services Marketing Quarterly, 34(4), 339-352, DOI: 10.1080/15332969.2013.827069

19. Han, H., Hsu, L-T., \& Lee, J. (2009). Empirical investigation of the roles of attitudes toward green behaviors, overall image, gender, and age in hotel customers' eco-friendly decision-making process. International Journal of Hospitality Management, 28, 519-528. DOI: $10.1016 /$ j.ijhm.2009.02.004

20. Han, H., Hsu, L-T.J., Lee, J-S., \& Sheu, C. (2011). Are lodging customers ready to go green? An examination of attitudes, demographics, and eco-friendly intentions. International Journal of Hospitality Management, 30(2), 345-355.

21. Hardeman, G., Font, X., \& Nawijn, J. (2017). The power of persuasive communication to influence sustainable holiday choices: Appealing to self-benefits and norms. Tourism Management, 59, 484-493.

22. Hinnen, G., Hille, S.L., \& Wittmer, A. (2017). Willingness to pay for green products in air travel: ready for take-off? Business Strategy and the Environment, 26, 197-208.

23. Hunt, C.A., \& Harbor, L.C. (2019). Pro-environmental tourism: Lessons from adventure, wellness and eco-tourism (AWE) in Costa Rica. Journal of Outdoor Recreation and Tourism, 28, DOI: doi.org/10.1016/j.jort.2018.11.007

24. Jurowski, C., Uysal, M., \& Noe, F.P. (1993). US Virgin Islands National Park: A factorcluster segmentation study. Journal of Travel and Tourism Marketing, 1(4), 3-31. 
25. Juvan, E., \& Dolnicar, S. (2014). The attitude--behaviour gap in sustainable tourism. Annals of Tourism Research, 48, 76-95. DOI: 10.1016/j.annals.2014.05.012

26. Kang, K.H., Stein, L., Heo, C.Y., \& Lee, S. (2012). Consumer's willingness to pay for green initiatives of the hotel industry. International Journal of Hospitality Management, 31(2), 564-572.

27. Kim, H., Borges, M. C., \& Chon, J. (2006). Impacts of environmental values on tourism motivation: The case of FICA, Brazil. Tourism Management, 27(5), 957-967. DOI: 10.1016/j.tourman.2005.09.007

28. Kim, Y. \& Han, H. (2010). Intention to pay conventional-hotel prices at a green hotel - a modification of the theory of planned behaviour. Journal of Sustainable Tourism, 18(8), 997-1014, DOI: 10.1080/09669582.2010.490300.

29. Kuminoff, N. V., Zhang, C., \& Rudi, J. (2010). Are travelers willing to pay a premium to stay at a "green" hotel? Evidence from an internal meta-analysis of hedonic price premia. Agriculture and Resource Economics Review, 39(3), 468-484.

30. Lee, J-S., Hsu, L-T., Han, H., \& Kim, Y. (2010). Understanding how consumers view green hotels: how a hotel's green image can influence behavioural intentions. Journal of Sustainable Tourism, 18(7), 901-914, DOI: 10.1080/09669581003777747.

31. Lew, D.K. (2015). Willingness to pay for threatened and endangered marine species: A review of the literature and prospects for policy use. Frontiers in Marine Science, 2. DOI: 10.3389/fmars.2015.00096.

32. Line, N., \& Costen, W. (2011). Environmental attitudes, motivation, and attachment: Toward a model of nature-based tourism. International CHRIE Conference-Refereed Track. 5. https://scholarworks.umass.edu/refereed/ICHRIE_2011/Wednesday/5

33. Line, N. D., \& Hanks, L. (2016). The effects of environmental and luxury beliefs on intention to patronize green hotels: The moderating effect of destination image. Journal of Sustainable Tourism, 24(6), 904-25.

34. Line, N., Hanks, L., \& Miao, L. (2018). Image matters: Incentivizing green tourism behavior. Journal of Travel Research, 57(3), 296-309.

35. Luo, Y., \& Deng, J. (2008). The new environmental paradigm and nature-based tourism motivation. Journal of Travel Research, 46, 392-402.

36. Manaktola, K., \& Jauhari, V. (2007) Exploring consumer attitude and behaviour towards green practices in the lodging industry in India. International Journal of Contemporary Hospitality Management, 19(5), 364-377, DOI: 10.1108/09596110710757534

37. Manganari, E.E., Dimara, E., \& Theotokis, A. (2016). Greening the lodging industry: Current status, trends and perspectives for green value. Current Issues in Tourism, 19(3), 223-242. 
38. Miao, L., and W. Wei. 2013. Consumers' pro-environmental behavior and the underlying motivations: A comparison between household and hotel settings." International Journal of Hospitality Management, 32, 102-12.

39. Millar, M., \& Baloglu, S. (2011). Hotel Guests' Preferences for Green Guest Room Attributes. Cornell Hospitality Quarterly, 52(3), 302-311. DOI: $10.1177 / 1938965511409031$

40. Millar, M. \& Mayer, K.J. (2013). A profile of travelers who are willing to stay in environmentally friendly hotel. Hospitality Review, 30(2).

http://digitalcommons.fiu.edu/hospitalityreview/vol30/iss2/5.

41. Nielsen Global Survey of Corporate Social Responsibility and Sustainability https://www.nielsen.com/uk/en/insights/news/2015/green-generation-millennials-saysustainability-is-a-shopping-priority.html

42. Nunnally, J. (1967). Psychometric theory. New York: McGraw-Hill.

43. Sánchez-Ollero, J. L., García-Pozo, A., \& Marchante-Mera, A. (2014). How does respect for the environment affect final prices in the hospitality sector? A hedonic pricing approach. Cornell Hospitality Quarterly, 55(1), 31-39. DOI: 10.1177/1938965513500709

44. Sánchez-Pérez, M., Illescas-Manzano, M.D., \& Martínez-Puertas, S. (2019). Modeling hotel room pricing: A multi-country analysis. International Journal of Hospitality Management, 79, 89-99. DOI: 10.1016/j.ijhm.2018.12.014

45. Seligman, M. E. P., \& Csikszentmihalyi, M. (2000). Positive psychology: An introduction. American Psychologist, 55 (1), 5-14. DOI:10.1037/0003-066X.55.1.5.

46. Singh, G., \& Pandey, N. (2018). The determinants of green packaging that influence buyers' willingness to pay a price premium. Australasian Marketing Journal, 26(3), 221230.

47. Susskind, A.M. (2014). Guests' reactions to in-room sustainability initiatives: An experimental look at product performance and guest satisfaction. Cornell Hospitality Quarterly, 55(3), 228-238. DOI: 10.1177/1938965514533744

48. Susskind, A.M., \& Verma, R. (2011). Hotel Guests' Reactions to Guest Room Sustainability Initiatives. cornell hospitality report, 11(6), 6-13. https://scholarship.sha.cornell.edu/cgi/viewcontent.cgi?article $=1135 \&$ context $=$ chrpubs

49. Sustainability Leaders Project. (2016). Interview with Richard Butler on sustainability and tourism education. https://sustainability-leaders.com/interview-richardbutler/?fbclid=IwAR1kf8vW6qlETgG6LzGJk5kc50jcJxalRA18rt6Ilhb6kQEtxlt_cGSKJ2 $\mathrm{E}$

50. Tajfel, H., \& Turner, J.C. (1986). "The social identity theory of intergroup behaviour". In S. Worchel \& W.G. Austin. Psychology of Intergroup Relations. Chicago, IL: NelsonHall. pp. 7-24. 
51. TripAdvisor (2015). Go Green - TripAdvisor Greenleaders ${ }^{\mathrm{TM}}$ Launches in Australasia. https://www.ecotourism.org.au/assets/Uploads/TripAdvisor-GreenLeaders-press-releaseAUS.pdf

52. Tsagarakis, K.P., Bounialetou, F., Gillas, K., Profylienou, M., Pollaki, A., \& Zografakis, N. (2011). Tourists' attitudes for selecting accommodation with investments in renewable energy and energy saving systems. Renewable and Sustainable Energy Reviews, 15(2), 1335-1342. DOI: 10.1016/j.rser.2010.10.009.

53. Watkins, E. B. (1994). Do guests want green hotels? Lodging Hospitality, 50(12), 70. Retrieved from https://search.proquest.com/docview/236523258?accountid=14680

54. Wearing, S., Cynn, S., Ponting, J. \& McDonald, M. (2002). Converting environmental concern into ecotourism purchases: A qualitative evaluation of international backpackers in Australia. Journal of Ecotourism, 1(2-3), 133-148, DOI: 10.1080/14724040208668120

55. Wurzinger, S., \& Johansson, M. (2006). Environmental concern and knowledge of ecotourism among three groups of Swedish tourists. Journal of Travel Research, 45(2), 217-226. DOI: $10.1177 / 0047287506291602$

56. Yesawich, P. C. (2008). Turning green practices into more green. Hotel \& Motel Management, 223(16): 14-14.

57. Zografos, C., \& Allcroff, D. (2007). The environmental values of potential ecotourists: A segmentation study. Journal of Sustainable Tourism, 15(1): 44-66. 